\title{
Readiness for autonomous English language learning: The case of Indonesian undergraduate students
}

\author{
Daflizar $^{1 *}$ and Eleni Petraki \\ ${ }^{1}$ English Education Department, Faculty of Education and Teacher Training, State Islamic Institute of Kerinci, \\ Jl. Kapten Muradi Kec. Pesisir Bukit, Sungai Penuh, Provinsi Jambi, Indonesia \\ ${ }^{2}$ Faculty of Education, University of Canberra, Bruce, ACT, 2601, Australia
}

\begin{abstract}
The purpose of this study was threefold: (1) to investigate how Indonesian undergraduate students perceive their teachers' and their responsibilities in English language learning; (2) to investigate how the students perceive their abilities related to autonomous English language learning; (3) to examine if there are differences in the students' perceptions of their responsibilities and abilities concerning gender and majors of study. The study employed a mixed-methods research approach with a sequential explanatory design and recruited 402 participants in the quantitative phase and 30 participants in the qualitative phase. The data were collected through questionnaires and semi-structured interviews. The findings showed that the majority of students deemed the teacher to be the one in charge of their learning despite their positive perceptions of their abilities. No significant difference was found between males and females in their perceptions of responsibilities and abilities. Regarding majors of study, no significant difference was found between English major students and non-English majors in their perceptions of their abilities; however, there was a significant difference between the groups' perceptions of their responsibilities. The research advocates the need for awarenessraising on the benefits of learner autonomy and appropriate teacher training for the Indonesian context.
\end{abstract}

Keywords: Abilities; English major; gender; Indonesian tertiary students; learner autonomy; learning responsibilities

\begin{tabular}{|c|c|c|}
\hline $\begin{array}{l}\text { First Received: } \\
18 \text { May } 2021 \\
\text { Final Proof Received: } \\
26 \text { January } 2022\end{array}$ & $\begin{array}{c}\text { Revised: } \\
\text { 6 January } 2022\end{array}$ & $\begin{array}{c}\text { Accepted: } \\
\text { 22 January } 2022 \\
\text { Published: } \\
\text { 30 January 2022 }\end{array}$ \\
\hline $\begin{array}{l}\text { How to cite (in APA style): } \\
\text { Daflizar, D. \& Petraki, E. (2022). } \\
\text { case of Indonesian undergradu } \\
\text { 11(3), 515-526. https://doi.org }\end{array}$ & $\begin{array}{l}\text { ness for auton } \\
\text { udents. Indon } \\
\text { 7509/ijal.v11i }\end{array}$ & $\begin{array}{l}\text { glish language learning: The } \\
\text { inal of Applied Linguistics, }\end{array}$ \\
\hline
\end{tabular}

Accepted:

\section{INTRODUCTION}

Learner autonomy (LA) has attracted significant research attention over the past few decades. The growing interest in learner-centered and technologybased approaches to language teaching, coupled with the recent long-lasting COVID-19 pandemic, have resulted in the recognition and benefits of the learners' increased responsibility and active role in their learning. The literature clearly highlighted that LA increases learners' motivation (Dörnyei \& Csizér, 1998) and active participation in learning activities (Dincer et al., 2012; Miller et al., 2005) which leads to the improvement of their language proficiency (Dafei, 2007; Mohamadpour, 2013). LA also improves the quality of students' learning and allows them to make use of learning opportunities both inside and beyond the classroom (Cotterall, 1995; Palfreyman, 2003). In the English as a Foreign Language (EFL) context, such as Indonesia, the development of learner autonomy becomes more critical since the amount of exposure to English in the students' daily life setting is limited. Students' contact with English usually takes place only in the EFL classroom. Once leaving the classroom,

\footnotetext{
* Corresponding Author

Email: daflizar@yahoo.com
} 
students are inevitably submerged in their native language surroundings. Thus, to increase students' exposure to the target language, which is the indispensable precondition of language acquisition (Rowland, 2014), students need to take initiative and engage in autonomous English language-related activities beyond the classroom.

While LA has long been regarded as a concept emerging from and appropriate to the Western cultures and its relevance in different cultures has been debated (Benson, 2001, 2007; Benson \& Voller, 1997), current literature has suggested LA is a universal concept and applicable to all learners, no matter what culture they come from, as long as adjustments to the teaching contexts are made (Hsu, 2015). According to Hsu et al. (2019), these adjustments could be made to the aims of the course and curriculum, the needs and objectives of students' learning, the learning environment, and teaching methods. Thus, to identify the strategies needed for promoting LA in the classroom, it is important to examine the appropriateness of these strategies in the sociopolitical, cultural, and social contexts for which they are intended (Nguyen \& Gu, 2013).

In the Indonesian context, the challenges in English language teaching have resulted in many efforts from the government to improve its quality and many changes in the curriculum (Dardjowidjojo, 2000; Hamied, 2011; Kirkpatrick, 2007; Marcellino, 2008). Although the term learner autonomy is not explicitly mentioned in the educational discourse, the concept does exist at the conceptual level and efforts are made to promote it in the classroom (Cirocki et al., 2019). The term is implied in the 2013 high school curriculum indicating that its aim is to create lifelong learners to become competent humans who are proactive and independent in facing the local and global challenges, and the teaching-learning process aims to promote critical thinking, problem-solving, communication, creativity, innovation, and collaboration among students (Kemdikbud, 2017).

Research in the Indonesian context (e.g. Agustina, 2017; Lengkanawati, 2017) has revealed that teachers have their individual interpretations in the implementation of LA and acknowledge that the teachers' efforts are hindered by students' lack of motivation and the exam-focused curriculum in the English language teaching. Since all learning behavior is governed by beliefs and experience (Horwitz, 1988), understanding learners' beliefs is important as it can reveal whether learners have positive beliefs that could lead to successful learning or negative beliefs that could hinder their language learning. Thus, to succeed in fostering LA, teachers need to understand how their learners perceive autonomous learning and their responsibilities in learning. The research reported here aimed to address this gap and answer the following research questions to assist in the teachers' decision making and preparation:

1. How do Indonesian undergraduate students perceive their teachers' and their responsibilities for their English language learning?

2. How do the students perceive their abilities in autonomous English language learning?

3. Are there any statistically significant differences in the students' perceptions of their responsibilities and their abilities concerning gender and majors of study?

\section{Definitions of LA}

LA has been defined in many ways, demonstrating that it is a multifaceted concept (Benson, 2007; Smith, 2008) and there are diverse views on what it constitutes (Palfreyman, 2003). To start with, it is important to highlight that this paper draws on research on LA which is sometimes compared to self-regulated learning. We treat the latter as a narrower concept and one component of LA (Benson, 2013). In his report to the Council of Europe's Modern Language Project, Holec (1981) defined LA as "the ability to take charge of one's learning" (p. 3). Little (1991) defined autonomy as "a capacity - for detachment, critical reflection, decision-making, and independent action" (p. 4). According to Little, the capacity for autonomy is manifested in how learners go about their learning and how they transfer what they have learned to wider contexts. Pennycook (1997) regarded LA as "the struggle to become the author of one's own world, to be able to create own meanings, to pursue cultural alternatives amid the cultural politics of everyday life" (p. 39). Nguyen and Gu (2013) discuss LA as a combination of "willingness to learn" (p. 13), and self-regulation of learning which comprises self-management, planning, monitoring, and evaluating learning (p. 13). Despite the numerous views on the concept, there is a consensus that the term is best used to refer to the capacity to take control or take charge of one's own learning (Benson, 2013). The capacity, however, should not be understood as total independence from the teacher or as students learning in isolation. An autonomous learner learns through interaction and develops a sense of interdependence with others in the learning process (Benson, 2001; Little, 1991).

\section{Research on Students' Readiness for LA in Non- Western Contexts}

Students' readiness for LA has recently been a focus of research in non-Western contexts (e.g. Chan, 2001; Chan et al., 2002; Gamble et al., 2012; Koçak, 2003; Razeq, 2014; Üstünlüoğlu, 2009; Yıldırım, 2008). One of the earliest studies on learner readiness for autonomy was conducted by Chan (2001) with 20 second-year language major students on the 'English at the Workplace' course in the 
Hong Kong Polytechnic University. The results revealed strong indications of a highly positive attitude towards autonomous learning. The participants demonstrated that they had a clear understanding of the nature of learner autonomy and they were very much aware of its demands. However, the participants generally had an ambivalent attitude towards the teacher's role. On the one hand, a vast majority said they liked the teacher to explain what and how they were learning. On the other hand, a considerable proportion said that they liked the teacher to give them problems to work on and let them find their mistakes.

Similar research was conducted in the Turkish tertiary EFL context. Koçak's (2003) study revealed that the respondents viewed the teacher as being more responsible in some areas of learning but indicated their preferences for sharing the responsibilities equally in some other areas, including in stimulating their interest, identifying weaknesses and strengths, evaluating learning performance, evaluating English lessons, making sure they made progress during English lesson. In a similar context, Üstünlüoğlu's (2009) study found similar results, revealing that teachers took on most of the responsibilities, by perceiving their students were unqualified to fulfill their responsibilities. Somewhat different results, however, were revealed in Yildirım's (2008) study, in which the students seemed to be ready to take responsibility in many areas of learning.

In the Japanese context, Gamble et al. (2012) found that the students across motivational levels demonstrated the same perceptions of their responsibilities in performing autonomous learning tasks. They regarded the teachers as being more responsible for the learning areas relating to class management but felt that the areas related to assessment and setting learning goals should be shared equally with teachers. Razeq's (2014) study in the Palestinian context revealed that the students put the responsibilities for the success or failure of their language learning on their teachers. However, the students believed that they could perform autonomous learning if given the opportunity to do so. In the Iranian context, Farahani (2014) also found that the students viewed their teacher as a leading figure expected to make decisions in most areas of learning. However, the students were ready to share responsibility with their teacher in some areas of learning such as in deciding the objectives of the English course.

Although abundant research on students' readiness for LA has been conducted in the broad Asian context, scant research on this issue has been conducted specifically in the Indonesian context (e.g., Cirocki et al., 2019; Lamb, 2004; Lengkanawati, 2017; Mardjuki, 2018; Wachidah, 2001). A few preliminary research studies in the Indonesian context demonstrated that students have positive attitudes towards LA but this research is limited. Many of these studies did not specifically investigate students' readiness for LA. Lamb (2004) examined autonomous attitudes amongst 12 purposefully chosen EFL learners in provincial Indonesia during their first year in junior high school. Mardjuki (2018) looked at perceptions and attitudes of two male and two female EFL Indonesian post-graduate students in LA. Wachidah's (2001) study focused on student learning styles and autonomous learning involving 126 students in a Javanese-dominated general high school. To address the gap, this research attempted to provide a better understanding of the students' readiness to develop autonomous learning.

Studies on learner autonomy have also attempted to find the interaction between LA and motivation (Bacquet, 2017; Gardner \& Yung, 2015; Ma \& Ma, 2012), LA and gender (Kırmızı \& Kıraç, 2018; Koçak, 2003; Razeq, 2014), and LA and language proficiency (Jianfeng et al., 2018; Karatas et al., 2015; Mohamadpour, 2013). To extend the research on and gain further insights into the factors affecting LA, this study investigated the role of gender and major of study on students' perceptions of their readiness for autonomy. An analysis of the students' perceptions and readiness is hoped to complement the teachers' perspectives and assist in offering suitable recommendations to teachers in that context.

\section{METHOD \\ Research Design}

The present study employed the mixed methods approach with a sequential explanatory design. The design consists of two sequential phases, beginning with the quantitative data collection and analysis followed by the qualitative data collection and analysis (Creswell \& Plano Clark, 2011). One of the most noteworthy advantages of the mixed methods approach is that it merges the strengths of both qualitative and quantitative research (Creswell \& Plano Clark, 2011). The quantitative and qualitative methods complement each other and allow the researcher to take advantage of the strengths of each and embark on a robust analysis of the data for more meaningful findings (Ivankova et al., 2006).

\section{Participants}

A total of 402 first-year students from four higher educational institutions in a province in Indonesia participated in the quantitative phase of the study. The participants comprised 192 males and 210 females which spread over 20 different majors of study and with varied English proficiency. In the second qualitative phase, 30 of the students, who had agreed to participate in the second phase of this research, were purposefully selected for interviews. The selection aimed to ensure representation from 
students who displayed varying levels of readiness, high to moderate to low, based on the results of the quantitative phase.

\section{Research Instruments}

A questionnaire adapted from Chan et al. (2002) was used to collect the data in the quantitative phase. This questionnaire was chosen because it incorporated several concepts of LA suggested in the literature (Chan et al., 2002) and had been employed in several previous studies (e.g., Farahani, 2014; Koçak, 2003; Razeq, 2014; Yıldırım, 2008). The adapted questionnaire comprised two sections. The first section consisted of 13 items focusing on students' perceptions of their teachers' and their responsibilities in several areas of English language learning both inside and outside the classroom. The participants rated their responses on a five-point scale from 'not at all' to 'completely'. The second section consisted of 11 items exploring students' perceptions of their abilities in a range of areas of English language learning both inside and outside the classroom. In this section, the participants rated their answers on a five-point scale from 'very poor' to 'very good'. The adapted questionnaire had high reliability with a Cronbach's alpha internal consistency coefficient of .91. Before being used for the data collection, the questionnaire was carefully translated into Bahasa Indonesia. The translation was proofread by an English language educator in an Indonesian higher education institution who is also very proficient in English. In the qualitative phase, face-to-face semi-structured interviews were employed to further explore the results of the quantitative phase to give a better understanding of the reasons behind the held perceptions. Both instruments were pilot tested with some students which led to reformulations of some questions, which aimed to improve students' understanding of the questions.

\section{Data Collection and Analysis}

One of the researchers visited the four institutions, talked to English language staff, and requested their assistance to distribute information letters and consent forms inviting students to participate in the study. The students who agreed to participate returned the signed consent forms. Before the administration of the questionnaire, the participants were requested to complete the questionnaire as honestly as they could and they were informed that the outcomes of the study would provide a better understanding of student beliefs about autonomous English language learning so that teachers would become more aware of their responsibilities as probed through students' beliefs. After the quantitative analysis of the students' perceptions, one of the researchers contacted students who were interested in participating in the interviews and organized the interviews based on the students' availability. Before the interviews were conducted, it was emphasized that students' identities would be kept confidential and anonymous and that they were allowed to withdraw from the interview at any time. The interviews were conducted in Bahasa Indonesia to avoid miscommunication due to the low English proficiency level of the participants. The interviews were audio-recorded, transcribed verbatim, and then translated into English.

The questionnaire data were analyzed using descriptive statistics and non-parametric tests with the help of SPSS. The descriptive statistics used the percentages of students' responses to describe their perceptions of their teachers' responsibilities and perceptions of their abilities. Mann-Whitney U tests were used to examine the differences between female and male students and between the students of the English major and those of non-English majors in their perceptions of their responsibilities and abilities.

The interviews were analyzed using a thematic analysis following the steps proposed by Braun and Clarke (2006). Thematic analysis is a method for identifying, analyzing, and reporting themes (patterns) within data, which minimally organize and describe the data set in rich detail (Boyatzis, 1998). Clarke and Braun (2013) suggested that thematic analysis is a common systematic method of qualitative data analysis. It can be used for a wide variety of research questions, ranging from those concerning people's experiences or understandings to those regarding the representation and construction of particular phenomena in particular contexts, and can be relevant to generate data-driven or theory-driven analyses. The thematic analysis in this project involved initial examination and immersion in the data, preliminary identification of codes matched with individual transcript segments. This process was followed by rechecking the codes and the data segments by both researchers to eliminate overlap and redundancy. As with the quantitative results, the themes generated from the analysis were reported using percentages, as the number of interviewees was more than thirty allowing for quantitative analysis (Dörnyei, 2007). The quantitative and qualitative findings were then integrated.

\section{FINDINGS AND DISCUSSION Students' Perceptions of Their Teachers' and Their Responsibilities}

The results of the data analysis revealed that students regarded their teachers as being more responsible for many areas of learning than they were that can be seen in Table 1 . 
Table 1

Students' Perceptions of Their Teacher's Responsibilities

\begin{tabular}{|c|c|c|c|c|c|c|}
\hline Learning areas & Responsibility & $\begin{array}{c}\text { Completely } \\
(\%)\end{array}$ & $\begin{array}{c}\text { Mainly } \\
(\%)\end{array}$ & $\begin{array}{c}\text { Some } \\
(\%)\end{array}$ & $\begin{array}{c}\text { A little } \\
(\%)\end{array}$ & $\begin{array}{c}\text { Not at all } \\
(\%)\end{array}$ \\
\hline \multirow{2}{*}{$\begin{array}{l}\text { Making sure you make progress during } \\
\text { lessons }\end{array}$} & Yours & 11.44 & 39.80 & 36.82 & 11.69 & 0.25 \\
\hline & Teacher's & 14.18 & 50.75 & 28.86 & 5.97 & 0.25 \\
\hline \multirow{2}{*}{$\begin{array}{l}\text { Making sure you make progress } \\
\text { outside class }\end{array}$} & Yours & 10.95 & 24.88 & 36.57 & 24.63 & 2.99 \\
\hline & Teacher's & 4.23 & 22.14 & 38.56 & 5.12 & 9.95 \\
\hline \multirow{4}{*}{$\begin{array}{l}\text { Stimulating your interest in learning } \\
\text { English } \\
\text { Identifying your weaknesses in English }\end{array}$} & Yours & 16.17 & 49.50 & 23.13 & 10.45 & 0.75 \\
\hline & Teacher's & 21.89 & 51.99 & 18.16 & 6.22 & 1.74 \\
\hline & Yours & 10.45 & 29.35 & 35.82 & 22.39 & 1.99 \\
\hline & Teacher's & 15.17 & 42.29 & 25.62 & 13.43 & 3.48 \\
\hline \multirow[t]{2}{*}{ Making you work harder } & Yours & 22.64 & 43.53 & 21.39 & 10.95 & 1.49 \\
\hline & Teacher's & 16.17 & 44.03 & 26.37 & 1.94 & 1.49 \\
\hline \multirow{2}{*}{$\begin{array}{l}\text { Deciding the objectives of your English } \\
\text { course }\end{array}$} & Yours & 12.19 & 30.85 & 33.08 & 19.40 & 4.48 \\
\hline & Teacher's & 23.38 & 41.04 & 23.63 & 10.2 & 1.74 \\
\hline \multirow{2}{*}{$\begin{array}{l}\text { Deciding what you should learn next in } \\
\text { your English lessons }\end{array}$} & Yours & 7.96 & 27.36 & 32.09 & 24.88 & 7.71 \\
\hline & Teacher's & 27.86 & 41.29 & 22.64 & .72 & 1.49 \\
\hline Choosing what activities to use to learn & Yours & 7.21 & 25.87 & 33.33 & 26.12 & 7.46 \\
\hline English in your English lessons & Teacher's & 19.15 & 39.05 & 24.88 & 2.94 & 3.98 \\
\hline \multirow{2}{*}{$\begin{array}{l}\text { Deciding how long to spend on each } \\
\text { activity }\end{array}$} & Yours & 7.46 & 26.87 & 33.58 & 24.88 & 7.21 \\
\hline & Teacher's & 14.18 & 33.08 & 28.11 & 8.16 & 6.47 \\
\hline Choosing what materials to use to learn & Yours & 7.21 & 22.89 & 34.33 & 24.88 & 10.70 \\
\hline English in your English lessons & Teacher's & 25.62 & 41.04 & 23.13 & .46 & 1.74 \\
\hline \multirow[t]{2}{*}{ Evaluating your learning } & Yours & 10.45 & 42.04 & 28.36 & 16.42 & 2.74 \\
\hline & Teacher's & 22.39 & 50.75 & 20.65 & .48 & 1.74 \\
\hline \multirow[t]{2}{*}{ Evaluating your course } & Yours & 10.45 & 29.10 & 35.82 & 21.14 & 3.48 \\
\hline & Teacher's & 23.63 & 42.54 & 22.89 & .96 & 2.99 \\
\hline \multirow[t]{2}{*}{ Deciding what you learn outside class } & Yours & 19.40 & 26.87 & 26.87 & 19.90 & 6.97 \\
\hline & Teacher's & 7.71 & 21.64 & 29.85 & 2.39 & 18.41 \\
\hline
\end{tabular}

As shown in Table 1, more student responses congregated in the 'mainly' category of the scale, and more than $40 \%$ of the students chose this category in 9 out of 13 learning areas. Some $20 \%$ also chose the 'completely' category in several of these areas. The nine areas are:

- Stimulating students' interest in learning English

- Making sure they make progress during lessons

- Evaluating their learning

- Making them work harder

- Evaluating their course

- Identifying their weaknesses in English

- Deciding what they should learn next in the English lessons

- Deciding the objectives of their English course

- Choosing what materials to use to learn English in their English lessons

On the other hand, there were four areas for which a considerable number of the students preferred themselves taking more responsibility. The areas are: stimulating their interest in learning English, making them work harder, evaluating their learning, and deciding what they learn outside the class. Besides, more than $30 \%$ of the students chose 'some' in 9 out of the 13 areas of learning. Only $10 \%$ or less chose 'completely' and $30 \%$ or less chose 'mainly' for most of the tasks. Similarly, only $20 \%$ or less thought they had little or no responsibility for almost all tasks. This suggests that the students expected almost shared responsibility in the majority of the learning areas but also expected the teachers to take more responsibilities concerning their learning.

In the interview, the students were asked several questions to explore further their beliefs about the locus of learning responsibility and the reasons for their choices. The students were divided in their answers. For example, $30 \%$ recognized their role in their learning.

\section{Excerpt 1}

Sebagai seorang mahasiswa, saya kira mahasiswa itu sendiri yang harus lebih bertanggung jawab atas pembelajaran mereka. Mereka bukan siswa SD atau sekolah menengah lagi jadi mesti berusaha sendiri. (As a university student, I would say the students themselves should be more responsible for their learning. They are not primary or secondary school students anymore so they have to make their own effort). (S20)

Another $30 \%$, however, said that the teacher should take on more responsibilities.

\section{Excerpt 2}

Saya kira keduanya, dosen dan mahasiswa... tapi lebih kepada dosen karena kan tanggung jawabnya untuk mengajar mahasiswa. (I think both on the teacher and students... but more on the teacher 
because it is his/her responsibility to teach the students). (S27)

Some other students believed that both the teacher and the students should share equal responsibilities.

\section{Excerpt 3}

Mesti ada kerjasama antara dosen dan mahasiswa, contohnya mahasiswa bisa menyampaikan kepada dosen bagaimana cara belajar yang lebih mereka senangi. Jadi harus ada kesepakatan antara mereka. (There should be cooperation between the teacher and students, for example, students can make suggestions to the teacher about how they prefer to learn. So, there should be an agreement between them). (S1)

There was a general agreement among the interviewed students that the teacher should be responsible for learning that takes place inside the class, as this is related to the curriculum, while the students themselves should be responsible for learning out-of-class learning.

\section{Excerpt 4 \\ Kalau di ruang kelas, tanggung jawab seharusnya ya umumnya pada dosen, mereka mesti menentukan tujuan pembelajaran. Namun kalau diluar kelas ya tergantung dengan mahasiswa itu sendiri. (In the classroom, the responsibility should be mostly on the teacher, they should set the goals of learning. But outside the class, it depends on the students themselves). (S4)}

\section{Excerpt 5}

Dalam pendidikan formal, itu tanggung jawab dosen... kalau mencari materi tambahan diluar kelas serta menambah ilmu ya itu tanggung jawab mahasiswa itu sendiri. (In formal education, the responsibility should be on the teacher... but finding more materials outside the class and searching for more knowledge should be the responsibility of the students themselves). (S13)

A similar opinion was expressed by the majority of the students concerning choosing the learning materials. These opinions were consistent with the opinions given in the questionnaires.

\section{Excerpt 6}

Kalau untuk belajar di kelas, materinya harus disediakan oleh dosen sebab materinya kan kelanjutan dari materi yang sudah dipelajari dan dipahami siswa... Kalau diluar kelas... saya akan memilih sendiri materinya sehingga saya dapat menentukan dari mana saya bisa mulai. Saya akan tinggalkan dulu materi-materi yang sulit saya pahami. (For classroom learning, the materials should be provided by the teacher because they should be the continuation of what has been learned and understood by learners... For outside of class learning... I would choose the materials myself so I can determine where I can start. I will leave the materials that I find difficult to understand). (S8) Excerpt 7
Kalau memilih materi untuk pembelajaran di kelas itu tanggung jawab dosen sebab harus sesuai dengan kurikulum, tapi mahasiswa bertanggung jawab dalam memilih materi untuk mereka pelajari diluar kelas. (Choosing the materials for classroom learning is the teacher's responsibility because the materials should correspond to the curriculum, but the students should be responsible for choosing materials for their out-of-class learning). (S3)

As evident in the data above, the students viewed their teachers as central figures in their English language learning, that is, they preferred their teachers to take on the responsibilities in many areas of their learning. These results are in line with those achieved in several studies carried out in nonWestern contexts (Chan, 2001; Chan et al., 2002; Farahani, 2014; Koçak, 2003; Razeq, 2014; Üstünlüoğlu, 2009) and also seem to conform to claims made about Indonesian learners, namely that they are strongly inclined to accept teacher dominance and authority in the classroom (Cirocki et al., 2019). The teacher is often portrayed as a figure with authority who acts as the transmitter of knowledge and the planner of learning activities to whom the student must submit both inside and outside the classroom (Milner, 1996, p. 92) and the fountain of knowledge, "while knowledge is viewed as a more or less a fixed set of facts to be transmitted and digested by thirsty learners... (Lewis, 1997, p. 14). It has been suggested in the literature that teacher-centered education largely fails to encourage students' self-expression, creativity, and responsibility (Crumly et al., 2014; Garrett, 2008; Rogers \& Frieberg, 1994) so that learners may expect too much of their teachers.

To some extent, this teacher-centered orientation could be linked to certain philosophical and cultural values existing in the wider society in Indonesia. As Dardjowidjojo (2001, pp. 314-315) suggests, for some Indonesian ethnic groups, there is an ingrained belief called manut lan miturut suggesting that the measure used for judging whether a child is good or bad is based on the obedience towards his/her parents. This parental guidance is usually extended to the classroom, thus a child expressing personal views or disagreeing with the teacher may be contradictory to their cultural beliefs and social norms. In this regard, Wachidah (2001, p. 127) may be right when she points out "it may not be easy to change a pattern of classroom discourse that is laden with important cultural implications for both the teacher and the student." With the strong emphasis on rote learning and teacher-fronted classrooms, it is also possible to assume that students may not have been exposed to the strategies or activities which enable them to adopt self-independence, or appropriate scaffolding to allow them to consider such options. Given the role of LA in the Indonesian curriculum, and the development of lifelong learning skills as a result of 
learner autonomy, teachers can play a fundamental role in promoting autonomy-supported practices. The government and departments of higher education should invest in culturally specific teacher training to enhance teachers' abilities in encouraging learner autonomy in the second language classroom.

Despite the students' strong inclination to accept the teacher's control in many tasks, the majority of the students believed that they should take more responsibility in several learning areas, including stimulating their interest, making them work harder, making sure they make progress during lessons, and evaluating their learning. These responses suggest the students displayed signs of reactive than proactive autonomy (Littlewood, 1999). This means that the students take control over their learning and are happy to execute tasks after the direction or task has been set.

Students' Perceptions of Their Abilities in Autonomous English Language Learning

Table 2 displays the percentages of students' responses regarding their perceptions of their abilities in a range of English language learning activities. As seen in the table, the students' responses congregate in the 'good' and 'OK' categories of the scale: more than $30 \%$ of the students chose these two categories in ten out of the eleven items. The top five activities in which students rated their abilities as 'good' are: choosing learning objectives in class $(48.01 \%)$, choosing learning material in class $(42.79 \%)$, choosing learning activities in class (41.04\%), evaluating their course (39.05\%), and evaluating their learning $(38.31 \%)$. The top five activities in which students rated their abilities as 'OK' are: choosing learning activities outside class (50.00\%), deciding how long to spend on each activity (49.00\%), choosing learning objectives outside class $(48.26 \%)$, choosing learning materials outside class (46.27\%), and choosing learning activities in class (43.03\%). Also, some students rated their abilities as 'very good' in evaluating their learning (22.39\%) and choosing learning objectives in class $(20.15 \%)$. Only small percentages of the students rated their abilities as 'poor' or 'very poor' in any of the activities.

Table 2

Students' perceptions of their abilities in autonomous English language learning

\begin{tabular}{lccccc}
\hline \multicolumn{1}{c}{ Learning areas } & $\begin{array}{c}\text { Very good } \\
(\boldsymbol{\%})\end{array}$ & $\begin{array}{c}\text { Good } \\
(\boldsymbol{\%})\end{array}$ & $\begin{array}{c}\text { OK } \\
(\boldsymbol{\%})\end{array}$ & $\begin{array}{c}\text { Poor } \\
(\boldsymbol{\%})\end{array}$ & $\begin{array}{c}\text { Very poor } \\
(\boldsymbol{\%})\end{array}$ \\
\hline Choosing learning activities in class & 14.43 & 41.04 & 43.03 & 1.49 & 0 \\
Choosing learning activities outside class & 11.69 & 29.60 & 50.00 & 7.71 & 1.00 \\
Choosing learning objectives in class & 20.15 & 48.01 & 29.60 & 1.99 & 0.25 \\
Choosing learning objectives outside class & 9.95 & 32.09 & 48.26 & 8.21 & 1.49 \\
Choosing learning materials in class & 16.67 & 42.79 & 36.07 & 4.23 & 0.25 \\
Choosing learning materials outside class & 6.97 & 34.58 & 46.27 & 9.45 & 2.74 \\
Evaluating your learning & 22.39 & 38.31 & 33.33 & 5.22 & 0.75 \\
Evaluating your course & 16.42 & 39.05 & 38.81 & 4.48 & 1.24 \\
Identifying your weakness in English & 18.41 & 31.34 & 37.31 & 10.95 & 1.99 \\
Deciding what you should learn next in your & 13.68 & 35.82 & 41.29 & 7.96 & 1.24 \\
English lesson & & & & & \\
Deciding how long to spend on each activity & 8.21 & 34.83 & 49.00 & 6.72 & 1.24 \\
\hline
\end{tabular}

It may be worth noting that, as can be seen in Table 2, more students chose the 'good' or 'very good' categories compared to those who chose the 'OK' category for inside class activities. The activities are: choosing learning objectives (48.01\% 'good' and $20.15 \%$ 'very good'), choosing learning materials (42.79\% 'good' and $16.67 \%$ 'very good'), and choosing learning activities (41.04\% 'good' and $14.43 \%$ 'very good'). On the other hand, more students chose the 'OK' than 'good' or 'very good' categories of the scale for outside class activities, which include choosing learning activities (50.00\%), choosing learning objectives (48.26\%), and choosing learning materials $(46.27 \%)$.

When asked in the interviews, the students highlighted some of the reasons for their responses. One of the reasons for not rating their abilities higher was that they were not used to performing all these activities.

\section{Excerpt 8}

Salah satu alasannya adalah saya tidak terbiasa melakukan semua ini. (One reason is that I am not used to doing all these). (S20)

Another commonly cited reason was the influence of the unsupportive learning environment, such as lack of motivation from friends. Meanwhile, some saw it as a result of limited learning resources and the difficulty of learning English in an underresourced EFL context.

\section{Excerpt 9}

Pertama ya karena kurangnya buku-buku berbahasa Inggris dan kedua karena susah mencari 
orang untuk mempraktekkan bahasa Inggris. (Firstly, this is because of the shortage of English books and secondly, it is very difficult to find people to practice English). (S4)

However, when asked about their perceptions of LA, all the students regarded LA as an indispensable element of language learning. They showed willingness and interest in becoming more autonomous, which they considered important for compensating for time and resource scarcity, broadening knowledge, and offering personalized learning. Some of the students' responses corroborate these views.

\section{Excerpt 10 \\ Kita tidak selalu mendapatkan apa yang kita butuhkan bila kita hanya bergantung kepada dosen. Dosen tidak selalu ada untuk mengajarkan apa yang ingin kita pelajari. (We will not always get what we need if we rely solely on the teachers. The teachers will not always be available to teach what we want to learn). (S24) \\ Excerpt 11 \\ Belajar secara mandiri dapat memperluas pengetahuan kita dan menambah apa-apa yang sudah kita pelajari dari materi-materi yang diberikan di kelas. (Learning by ourselves can also broaden our knowledge and add to what we learned from the lessons in the classroom). (S17)}

The above responses demonstrated that the students had positive views about their abilities regarding autonomous English learning activities both inside and outside the classroom. These results are in line with those revealed in other studies conducted in non-Western countries or contexts (e.g., Chan 2001; Chan et al., 2002; Razeq, 2014; Üstünlüoğlu, 2009; Yıldırım, 2008) in which the respondents viewed their abilities positively. One possible explanation for the students' positive views about their abilities is that their age and maturity have developed their understanding of LA and helped them feel confident to exercise these autonomy-related activities. This is in line with what Grow (1991, p. 127) maintains, that "Self-direction, is partly a personal trait analogous to maturity." With the understanding that the students viewed their abilities positively, the teacher could use this to further their language learning and at the same time reinforce these abilities by employing more autonomy-oriented activities in the classroom.

It is worth noting, however, that the students in this study appeared to feel that their abilities for inside class activities are better than those of outside class activities. These results were unexpected, taking into account the teacher-centered nature of classroom instruction practice in the Indonesian context, in which the locus of responsibility for most classroom teaching and learning processes is usually in the hands of the teacher. However, it may hint at the students' lack of engagement in out-of-class learning which should be the subject in future research.

\section{Table 3}

Mann-Whitney $U$ Test Results of the Differences in Students' Perceptions of Their Responsibilities Depending on Gender ( $N=402)$

\begin{tabular}{lr}
\hline \multicolumn{2}{c}{ Responsibilities } \\
\hline Mann-Whitney U & 18619.500 \\
Female mean rank & 208.84 \\
Male mean rank & 193.48 \\
$z$-score & -1.325 \\
$p$-value & .185 \\
\hline
\end{tabular}

\section{Table 4}

The Mann-Whitney U Test Results of the Differences in Students' Perceptions of Their Abilities Depending on Gender $(N=402)$

\begin{tabular}{lr}
\hline & \multicolumn{1}{c}{ Abilities } \\
\hline Mann-Whitney U & 19900.000 \\
Female mean rank & 202.74 \\
Male mean rank & 200.15 \\
$z$-score & -.224 \\
$p$-value & .823 \\
\hline
\end{tabular}

Regarding majors of study, the responsibility perception level of the English major students (Mean rank $=251.11, \mathrm{n}=52$ ) is significantly higher than that of the non-English major students (Mean rank $=194.13, \mathrm{n}=350), U=6520.500, z=-3.303$ (corrected for ties), Sig. $=.001(p<.05)$, two-tailed. However, there was no significant difference in the level of perceptions of abilities between the students of the English major (Mean rank $=179.34, \mathrm{n}=52$ ) and the students of non-English majors (Mean rank $=204.79, \mathrm{n}=350), U=7947.500, z=-1.477$, Sig. $=$ .140 ( $p>.05$ ), two-tailed (See Table 5 and Table 6 below).

\section{Table 5}

Mann-Whitney U Test Results of the Differences in Students' Perceptions of Their Own Responsibilities Regarding Majors of Study $(N=402)$

\begin{tabular}{lr}
\hline & Responsibilities \\
\hline Mann-Whitney U & 6520.500 \\
English major mean rank & 251.11 \\
Non-English major mean rank & 194.13 \\
$z$-score & -3.303 \\
$p$-value & .001 \\
\hline
\end{tabular}

\section{Table 6}

Mann-Whitney U Test Results of the Students' Perceptions of Their Abilities Regarding Majors of Study $(N=402)$

\begin{tabular}{lr}
\hline & \multicolumn{1}{c}{ Abilities } \\
\hline Mann-Whitney U & 7947.500 \\
English major mean rank & 204.79 \\
Non-English major mean rank & 179.34 \\
$z$-score & -1.477 \\
$p$-value & .140 \\
\hline
\end{tabular}


Nasri et al. (2017) identified the importance of investigating differences in gender and education degree in student beliefs on learner autonomy. Such insights can assist teachers in designing contextspecific strategies for promoting learner autonomy. Our study found that there was no significant difference in the perceptions of the students' abilities between female and male students. The results were similar to those in Razeq's (2014) study in the Palestinian context. Interestingly, no significant difference was found in the perceptions of abilities between English major and non-English major students. This suggests that both groups of students had confidence in their abilities to engage in autonomous learning and that there is potential in promoting LA in the Indonesian classroom.

This was the first study that examined differences between English major and non-English major students in the Indonesian context. A significant finding was that the difference in the perceptions of responsibilities between these two groups was statistically significant. This finding suggests that students studying to be English language teachers may consider improvement in the learning of English as their lifelong goal and stronger interest in language learning. Due to their efforts to become role models in English language teaching, they are expected to assume more responsibility towards their learning and their teaching career and be aware of the importance of independent learning. Students' ideal L2 selves as discussed by Dörnyei and Ushioda (2009) are an integral aspect of these learners' motivational system and their awareness of the benefits of LA might be factors that contribute to the development of autonomy. It aligns with suggestions by Nguyen (2009) who argued that willingness to learn and intrinsic motivation are closely linked to learner autonomy. Besides, it is possible that the English major students were more aware of the benefits of LA in language learning through their studies and valued independent learning. These students had an immediate need to learn English and improve themselves as they envisaged their future selves as competent English teachers who needed to teach others, thus recognizing the need for continuous learning (Dörnyei \& Ushioda, 2009). As this is the first study to the researchers' knowledge that examined this relationship, it should be explored in future research in other contexts.

\section{CONCLUSION}

This study is the first systematic inquiry that investigated EFL university students' perceptions of their teachers' and their responsibilities and their abilities in autonomous English language learning in an Indonesian higher education context. This study also extended previous research on students' readiness for developing LA, especially in the Asian context. This study elaborated on the relationship between students' abilities and responsibilities and their majors of study as well as gender, which has not received much research attention. The results revealed that the Indonesian students viewed their teachers as being more responsible for many areas of learning even when they had positive views about their abilities. The results are explained by the students' previous learning experience, which has been dominated by teacher-centered pedagogy and rote learning, and by the cultural aspects of teaching, in which students are expected to respect the teachers' roles. The study revealed no significant differences in students' abilities and responsibilities with regards to gender but it found a significant difference between English major and non-English major students in their perceptions of their responsibilities.

The results demonstrate the need for promoting LA in the Indonesian EFL classroom. While LA is addressed in the curriculum, it may not be implemented consistently nor promoted in the same way. It should be acknowledged that it may not be easy to transfer control from the teacher to the students whose learning styles have been deeply ingrained in teacher-centered pedagogies and rote learning practices. A gradual transition may be needed to make the students more aware of the benefit of LA, be able to recognize their beliefs and abilities in the process, and allow them to take more responsibilities. Hence, learner training, used interchangeably with strategy training or learningto-learn training (Rivera-Mills \& Plonsky, 2007), are needed as an intermediary phase during which control is gradually transferred from the teacher to students. Teacher training on the benefits of LA, awareness, and practice in the development of context-specific autonomy-supportive practices can raise teachers' awareness of LA and their pedagogical skills in second language learning. As for the pedagogical approach, Little (2007) suggested three principles teachers should integrate into the design of activities as a way of enhancing learner autonomy: learner involvement, learner reflection, and target language use. Teachers should draw their learners into their own learning process, making them share responsibility for, such as choosing learning materials and activities, managing classroom interaction, and evaluating learning outcomes, reflect on what they are doing, and use the target language as the medium of communication in all classroom activities.

As with any research, the present study has some limitations. First, it involved a small number of institutions of higher education which were located in only one of the provinces in Indonesia. It is recommended that future research involve a bigger range of universities from different geographical areas to enhance the level of representativeness of the study and to provide a 
more comprehensive picture of Indonesian EFL university students' perceptions of their teachers' and their responsibilities and their abilities in autonomous English language learning. Second, it only assessed students' readiness for LA only through students' beliefs based on a questionnaire and interviews rather than looking at their actual practices. Other data collection methods such as learning diaries, portfolio assignments, classroom observations, etc. may be needed to discover the very nature of students' actual autonomous practices.

\section{ACKNOWLEDGEMENTS}

The research reported in this paper was supported by the 5000 Doctor Scholarship Program of the Indonesian Ministry of Religious Affairs.

\section{REFERENCES}

Agustina, D. (2017). Teachers' understanding of learner autonomy in Indonesian contexts: Findings from high schools and their implications. Language and Language Teaching Journal, 20(02), 127-132. https://doi.org/10.24071/llt.2017.200206

Bacquet, G. E. (2017). The link between autonomy and motivation and their effect in the learning process of Burmese English-language learners (27820658). [Master's thesis, University College London]. ProQuest Dissertations Publishing.

Benson, P. (2001). Teaching and researching autonomy in language learning. Longman.

Benson, P. (2007). Autonomy in language teaching and learning. Language Teaching, 40(1), 2140 . https://doi.org/10.1017/s0261444806003958

Benson, P. (2013). Teaching and researching autonomy (2nd ed.). Routledge.

Benson, P., \& Voller, P. (1997). Introduction: Autonomy and independence in language learning. In P. Benson \& P. Voller (Eds.), Autonomy and independence in language learning (pp. 1-17). Addison Wesley Longman.

Braun, V., \& Clarke, V. (2006). Using thematic analysis in psychology. Qualitative Research in Psychology, 3(2), 77-101. https://doi.org/10.1191/1478088706qp063oa

Chan, V. (2001). Readiness for learner autonomy: What do our learners tell us? Teaching in Higher Education, 6(4), 505-518. https://doi.org/10.1080/13562510120078045

Chan, V., Spratt, M., and Humphreys, G. (2002). Autonomous language learning: Hong Kong tertiary students' attitudes and behaviours. Evaluation \& Research in Education, 16(1), 118.
Cirocki, A., Anam, S., \& Retnanigdyah, P. (2019). Readiness for autonomy in English language learning: The case of Indonesian high school students. Iranian Journal of Language Teaching Research, 7(2), 1-18. https://dx.doi.org/10.30466/ijltr.2019.120695

Clarke, V., \& Braun, V. (2013). Teaching thematic analysis: Overcoming challenges and developing strategies for effective learning. The Psychologist, 26(2), 120-123.

Cotterall, S. (1995). Readiness in autonomy: Investigating learner beliefs. System, 23(2), 195-205.

Creswell, J. W., \& Plano Clark, V. L. (2011). Designing and conducting mixed methods research (2nd ed.). Sage.

Crumly, C., Dietz, P., \& d'Angelo, S. (2014). Pedagogies for student-centered learning: Online and on-ground. Fortress Press.

Dafei, D. (2007). An exploration of the relationship between learner autonomy and English proficiency. The Asian EFL Journal, 24, 1-23. https://www.asian-efl-journal.com/monthlyeditions-new/an-exploration-of-therelationship-between-learner-autonomy-andenglish-proficiency/

Dardjowidjojo, S. (2000). English teaching in Indonesia. English Australia Journal, 18(1), 21-30.

Dardjowidjojo, S. (2001). Cultural constraints in the implementation of learner autonomy: The case in Indonesia. Journal of Southeast Asian Education, 2(2), 309-322.

Dincer, A., Yesilyurt, S., \& Takkac, M. (2012). The effect of autonomy supportive climates on EFL learners' engagement, achievement and competence in English speaking classrooms. Procedia - Social and Behavioral Sciences, 46 , 3890-3894.

Dörnyei, Z. (2007). Research methods in applied linguistics: Quantitative, qualitative and mixed methodologies. Oxford University Press.

Dörnyei, Z., \& Csizér, K. (1998). Ten commandments for motivating language learners: Results of an empirical study. Language Teaching Research, 2, 203-229.

Dörnyei, Z., \& Ushioda, E. (2009). Motivation, language identities and the L2 self: A theoretical overview. In Z. Dörnyei \& E. Ushioda (Eds.), Motivation, language identity and the L2 self (pp. 1-8). Multilingual Matters.

Farahani, M. (2014). From spoon feeding to selffeeding: Are Iranian EFL learners ready to take charge of their own learning? Electronic Journal of Foreign Language Teaching, 11(1), 98-115.

Gamble, C., Aliponga, J., Wilkins, M., Koshiyama, Y., Yoshida, K., \& Ando, S. (2012). Examining learner autonomy dimensions: 
Students' perceptions of their responsibility and ability. In A. Stewart \& N. Sonda (Eds.), JALT2011 Conference Proceedings. JALT.

Gardner. D., \& Yung, K. W. H. (2015). Learner motivation in self-access language learning. Innovation in Language Learning and Teaching. https://doi.org/10.1080/17501229.2015.108854 5

Garrett, T. (2008). Student-centered and teachercentered classroom management: A case study of three elementary teachers. Journal of Classroom Interaction, 43.1, 34-47. https://files.eric.ed.gov/fulltext/EJ829018.pdf

Grow, G. O. (1991). Teaching learners to be selfdirected. Adult Education Quarterly, 41(3), 125-149. http://thinkteaching.pbworks.com/f/Grow01.pd $\mathrm{f}$

Hamied, F. A. (2011). English as a Lingua Franca: An Indonesian perspective [A plenary presentation]. The Fourth International Conference of English as a Lingua Franca, Hong Kong.

Holec, H. (1981). Autonomy and foreign language learning. Pergamon Press.

Horwitz, E. K. (1988). The beliefs about language learning of beginning university foreign language students. The Modern Language Journal, 72(3), 283-294.

Hsu, W. (2015). Learner autonomy in the eastern and western contexts. In L. T. Wong \& A. Jubey-Jhaveri (Eds.), English language education in a global world: Practices, issues and challenges (pp. 35-46). Nova Publishers.

Hsu, W., Ling, X., \& Xuelian, X. (2019). An investigation of responsibility and learner autonomy in a Sino-British EAP program in China. Journal of Asia TEFL, 16(1), 220-234. http://doi.org/10.18823/asiatefl.2019.16.1.14.2 20

Ivankova, N. V., Creswell, J. W., \& Stick, S. L. (2006). Using mixed-methods sequential explanatory design: From theory to practice. Field Methods, 18(1), 3-20. https://doi.org/10.1177/1525822X05282260

Jianfeng, C., Raj, G. S., \& Ai, J. T. T. (2018). The relationship among learning strategy, autonomy and language proficiency of Chinese EFL learners. International Journal of Foreign Language Teaching \& Research, 6(23), 23-34. http://jfl.iaun.ac.ir/article_607104.html

Karatas, H., Alci, B. Yurtseven, N., \& Yuksel, H. G. (2015). Prediction of ELT students' academic (language) achievement: Language learning orientation and autonomous learning. International Online Journal of Educational Sciences, 7(1), 160-171.

Kemdikbud. (2017). Panduan implementasi kecakapan abad 21 Kurikulum 2013 di Sekolah
Menengah Atas [Guidebook for the implementation of the 21 century skills of the 2013 Curriculum in High School level]. Kemdikbud.

Kirkpatrick, A. (2007). Teaching English across cultures: What do English language teachers need to know to know how to teach English? English Australia Journal, 23(2), 20-36.

Kırmızı, Ö. \& Kıraç, K. (2018). A comparative study of learner autonomy in terms of gender and learning contexts. Atatürk Üniversitesi Sosyal Bilimler Enstitüsü Dergisi, 22, 29552967. https://dergipark.org.tr/en/pub/ataunisosbil/issu e/42067/474815

Koçak, A. (2003). A study on learners' readiness for autonomous learning of English as a foreign language [Unpublished master's thesis]. Middle East Technical University.

Lamb, M. (2004). 'It depends on the students themselves': Independent language learning at an Indonesian state school. Language, Culture and Curriculum, 17(3), 229-245.

Lengkanawati, N. S. (2017). Learner autonomy in the Indonesian EFL settings. Indonesian Journal of Applied Linguistics, 6(2), 222-231. https://doi.org/10.17509/ijal.v6i2.4847

Lewis, R. (1997). Learning styles in transition: A study of Indonesian students. ERIC. https://files.eric.ed.gov/fulltext/ED421862.pdf

Little, D. (1991). Learner autonomy 1: Definitions, issues and problems. Authentik.

Little, D. (2007). Language learner autonomy: Some fundamental considerations revisited. Innovation in Language Learning and Teaching, 1(1), 14-29.

Littlewood, W. (1999). Defining and developing autonomy in East Asian contexts. Applied Linguists, 20(1), 71-94. https://doi.org/10.2167/illt040.0

Ma, Z., \& Ma, R. (2012). Motivating Chinese students by fostering learner autonomy in language learning. Theory and Practice in Language Studies, 2(4), 838-842. 10.4304/tpls.2.4.838-842

Marcellino, M. (2008). English language teaching in Indonesia: A continuous challenge in education and cultural diversity. TEFLIN Journal, 19(1), 57-69.

Mardjuki, M. S. (2018). Learner autonomy: Genderbased perception among EFL Indonesian students. IJEFL (Indonesian Journal of EFL and Linguistics), 3(1), 1-17.

Miller, L., Hopkins, M., \& Tsang, E. (2005). Selfaccess language learning in Hong Kong secondary schools. Paper presented at the 2nd Independent Learning Association Oceania Conference, Manukau Institute of Technology, Auckland, New Zealand. 
Milner, A. (Ed.). (1996). Australia in Asia: Comparing cultures. Oxford University Press.

Mohamadpour, P. (2013). Realization of autonomy and English language proficiency among Iranian high school students. Theory and Practice in Language Studies, 3(7), 11871193.

Nasri, N., Dastjerdy, H. V., Rasekh, A. E., \& Amirian, Z. (2017). Iranian EFL teachers' practices and learner autonomy: Do gender, educational degree, and experience matter? Innovation in Language Learning and Teaching, 11(2), 146-158. https://doi.org/10.1080/17501229.2015.107833 7

Nguyen, L. T. C., \& Gu, Y. (2013). Strategy-based instruction: A learner-focused approach for developing learner autonomy. Language Teaching Research, 17(1), 9-30. https://doi.org/10.1177/1362168812457528

Nguyen, L. T. C. (2009). Learner autonomy and EFL learning at the tertiary level in Vietnam [Unpublished doctoral dissertation]. Victoria University of Wellington.

Palfreyman, D. (2003). Introduction: culture and learner Autonomy. In D. Palfreyman \& R. C. Smith (Eds.), Learner autonomy across cultures: Language education perspectives (pp. 1-19). Palgrave Macmillan.

Pennycook, A. (1997). Cultural alternatives and autonomy. In P. Benson and P. Voller (Eds.),
Autonomy and independence in language learning (pp. 35-53). Longman.

Razeq, A. A. A. (2014). University EFL learners' perceptions of their autonomous learning responsibilities and abilities. RELC Journal, 45(3), 321-326.

Rivera-Mills, S. V., \& Plonsky, L. (2007). Empowering students with language learning strategies: A critical review of current issues. Foreign Language Annals, 40(3), 535-548.

Rogers, C., \& Frieberg, H. J. (1994). Freedom to learn (3rd ed.). Merrill Publishing.

Rowland, C. (2014). Understanding child language acquisition. Routledge.

Smith, R. (2008). The history of learner autonomy. In L. Dam (Ed.), 9th Nordic conference on developing learner autonomy in language learning and teaching: status and ways ahead after twenty years, 2006. CVU.

Wachidah, S. (2001). EFL learning autonomy and output planning: A case in a Javanesedominated general high school (Sekolah Menengah Umum) in Indonesia [Unpublished doctoral dissertation]. University of Sydney.

Üstünlüoğlu, E. (2009). Autonomy in language learning: Do students take responsibility for their learning? Journal of Theory and Practice in Education, 5(2), 148-169.

Yıldırım, Ö. (2008). Turkish EFL learners' readiness for learner autonomy. Journal of Language and Linguistic Studies, 4(1), 65-80. 